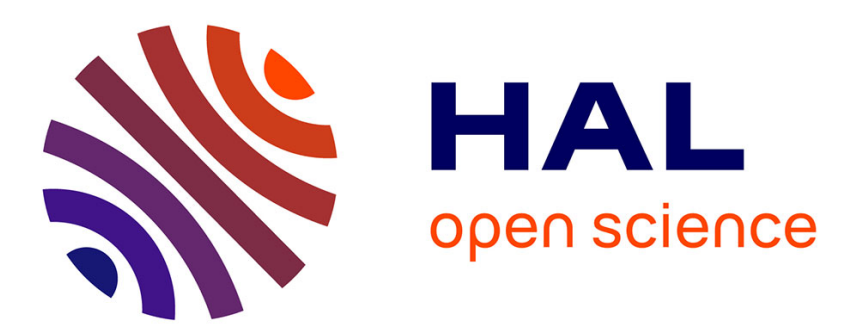

\title{
An MHC-linked locus modulates thymic differentiation of CD4+CD25+Foxp3+ regulatory $\mathrm{T}$ lymphocytes.
}

\author{
Julie Tellier, Joost Pm van Meerwijk, Paola Romagnoli
}

\section{To cite this version:}

Julie Tellier, Joost Pm van Meerwijk, Paola Romagnoli. An MHC-linked locus modulates thymic differentiation of CD4+CD25+Foxp3+ regulatory T lymphocytes.. International Immunology, 2006, 18 (11), pp.1509-19. 10.1093/intimm/dxl084 . inserm-00140905

\section{HAL Id: inserm-00140905 https://www.hal.inserm.fr/inserm-00140905}

Submitted on 15 Oct 2007

HAL is a multi-disciplinary open access archive for the deposit and dissemination of scientific research documents, whether they are published or not. The documents may come from teaching and research institutions in France or abroad, or from public or private research centers.
L'archive ouverte pluridisciplinaire HAL, est destinée au dépôt et à la diffusion de documents scientifiques de niveau recherche, publiés ou non, émanant des établissements d'enseignement et de recherche français ou étrangers, des laboratoires publics ou privés. 
Transmitting editor: Eric Vivier

\section{AN MHC LINKED LOCUS MODULATES THYMIC DIFFERENTIATION OF CD4 ${ }^{+} \mathrm{CD}^{2} 5^{+} \mathrm{FOXP}^{+}{ }^{+}$REGULATORY T LYMPHOCYTES}

Julie Tellier*, Joost P.M. van Meerwijk ${ }^{* \dagger}$, and Paola Romagnoli*

*Centre de Physiopathologie de Toulouse Purpan, Institut National de la Santé et de la Recherche Médicale (Inserm) U563, Toulouse, France; University Paul Sabatier, Toulouse, France; IFR 30, Institut Claude de Preval, Toulouse, France, and ${ }^{\dagger}$ Institut Universitaire de France and Faculty of life-sciences (UFR-SVT), University Paul Sabatier, Toulouse, France

Running title: $\quad$ MHC-linked genes modulate Treg development

Corresponding author: Joost P.M. van Meerwijk, INSERM U563, BP 3028, 31024

Toulouse Cedex 3, France, Phone (33) 5627483 81, FAX (33) 562

7445 58, E-mail: Joost.van-Meerwijk@toulouse.inserm.fr

Keywords: $\quad$ Thymus, Tolerance, T cells

Total number of pages: 25 text-pages, 7 figure-pages, 1 table

This is a pre-copy-editing, author-produced PDF of an article accepted for publication in International Immunology following peer review. The definitive publisher-authenticated version International Immunology 2006 18(11):1509-1519; is available online at: http://intimm.oxfordjournals.org/cgi/content/full/18/11/1509. 


\section{Abstract}

$\mathrm{CD} 4^{+} \mathrm{CD} 25^{+} \mathrm{Foxp}^{+}$regulatory $\mathrm{T}$ lymphocytes are crucial for maintenance of immunological tolerance to self and innocuous non-self, are known to modulate immunity to tumors and infectious agents, and can induce transplantation tolerance. Surprisingly, only a single genetic polymorphism is known to modulate regulatory $\mathrm{T}$ cell development in the thymus, leading to a lethal autoimmune disorder. Here we show that considerably different levels of regulatory $\mathrm{T}$ cells are found in thymi of distinct common laboratory mouse strains. We demonstrate that distinct levels of phenotypically and functionally identical regulatory $\mathrm{T}$ cells develop with similar kinetics in the studied mice, that the responsible locus acts in a thymocyte intrinsic manner, and that levels of thymic Foxp $3^{+}$regulatory $\mathrm{T}$ cells correlate to those found in the periphery. Using several congenic mouse-strains we mapped one of the at least two genetic loci capable of quantitatively modulating thymic regulatory $\mathrm{T}$ cell development to a $\leq 2.2$ Mbp region telomeric to the MHC. Our data indicate that polymorphic genes closely linked to the MHC locus substantially modulate differentiation of regulatory $\mathrm{T}$ cells. Identification of responsible genes should help in understanding mechanisms involved in commitment to the regulatory $\mathrm{T}$ cell lineage as well as selection of these cells in the thymus. 


\section{Introduction}

Among the several mechanisms assuring $\mathrm{T}$ lymphocyte tolerance to self, $\mathrm{CD} 4^{+} \mathrm{CD} 25^{+} \mathrm{FoxP} 3^{+}$ regulatory $\mathrm{T}$ cells (Treg) play a central and crucial role. Absence of these cells in experimental or clinical settings causes severe autoimmunity, and eventually may lead to death. Treg do not only inhibit autoimmunity, they also inhibit or fine-regulate immunity to tumors and infection, and prevent inflammatory bowel disease in mice. These cells are also involved in transplantation tolerance; they can inhibit Graft-versus-host disease as well as allograft rejection (1-6).

Given the potent immunomodulatory potential of Treg, it is not very surprising that they have recently received a lot of attention. However, not a lot is known about their development. Treg differentiate in the thymus (7) and MHC class II expression by cortical epithelial cells is sufficient for their positive selection (8). Deletion of autospecific Treg can be induced by APC of bone-marrow origin $(9,10)$. These two features of thymic Treg selection cannot explain their autoreactive repertoire $(9,11,12)$. However, as compared to conventional $\mathrm{T}$ cell precursors, Treg precursors appear to be more resistant to deletion induced by epithelial cells (13-15). Moreover, in peripheral lymphoid organs autospecific Treg proliferate (11,16-19). Therefore, differences in central Treg development as well as in peripheral homeostasis probably explain their autoreactive repertoire.

A very intriguing question in $\mathrm{T}$ cell development is how multipotent precursors commit to the different $\mathrm{T}$ cell lineages developing in the thymus. Again, little is known about Treg commitment. Based on the observation that significantly increased proportions of Treg develop in TCR/antigen doubly transgenic mice, it has been suggested that high affinity MHC/peptide ligands can induce Treg commitment (20-23). However, it has recently been suggested that the increased percentages of $\mathrm{CD}^{+} \mathrm{CD} 8^{-}$(CD4SP) $\mathrm{CD} 25^{+}$thymocytes in TCR/ligand doubly transgenic mice are not due to increased positive selection of Treg, but 
rather to deletion of $\mathrm{CD} 4 \mathrm{SP} \mathrm{CD} 25^{-}$(but not $\mathrm{CD} 25^{\text {high }}$ ) thymocytes upon encounter of agonist ligand on thymic epithelial cells (13). The latter hypothesis, however, cannot explain our recent observation that in hematopoietic chimeras in which superantigens are exclusively presented by radioresistant thymic epithelial cells, substantially increased positive selection of superantigen-specific Foxp $3^{+}$Treg occurs (15). The data presented in the latter report support the view that agonist ligands enhance positive selection, rather than redirecting thymic precursors to the Treg lineage.

The question as to how precursor thymocytes commit to the Treg lineage remains therefore unanswered. Knowledge on genetic polymorphisms leading to differences in thymic Treg development could contribute to our understanding of Treg commitment as well as of selection of these cells in the thymus.

Differences in Treg development may also modulate susceptibility to autoimmunity, cancer, and inflammatory bowel disease, and may even influence development of immunological memory. Despite these important considerations, only a single genetic polymorphism modulating thymic Treg development has been identified thus far. Mutations in the gene encoding the forkhead/winged helix transcription factor Foxp3, located on the $\mathrm{X}$ chromosome, lead to a complete absence of $\mathrm{CD} 4^{+} \mathrm{CD} 25^{+}$regulatory $\mathrm{T}$ cell development in mice (24-26). Foxp3-inactivation leads to a rapid death of affected males in the Mouse and to the autoimmune disease IPEX in Man (27-29). Forced expression of Foxp3 in mouse or human CD25 $\mathrm{T}$ cells endows these cells with regulatory capacity (24-26,30). Moreover, $\mathrm{CD} 4^{+} \mathrm{CD} 25^{+}$regulatory express Foxp3, and naturally occurring $\mathrm{CD} 25^{-} \mathrm{Foxp}^{+} \mathrm{T}$ cells have regulatory capacity (31). Therefore, Foxp3 is clearly a master switch in Treg development. However, the precise mechanisms leading to induction of Foxp3-expression during Treg development remain unclear. 
We have recently described that regulatory $\mathrm{T}$ cell development is quantitatively controlled by as yet unidentified genetic factors. In distinct strains of common laboratory mice we found small but statistically significant differences in thymic development of CD4SP CD25 ${ }^{\text {high }}$ Treg (32). Here, we show that genes linked to the MHC very substantially modulate differentiation of mature Treg from their immature precursors. We mapped a responsible locus to a $\leq 2.2$ Mbp region telomeric to the MHC. Ultimate identification of responsible genes should lead to a better understanding of Treg commitment, selection, and potentially function. 


\section{Methods}

Mice

All mice were females of 5 to 7 weeks of age. C57BL/6N (B6), CBA, BALB/c, C3H, (B6xDBA/2)F1 (B6D2F1) and (B6xCBA)F1 (B6CBAF1) mice were purchased from Janvier (Le Genest St Isle, France), C57BL/10 (B10), B10.BR, BALB.K, B10.A, B10.A(2R), and AKR strains from Harlan France (Gannat, France), and C57BR animals from Jackson Laboratories (Bar Harbor, MN, USA). B6 Thy1.1 and (B6xB10.BR)F ${ }_{1}$ mice were raised in our animal facilities. MHC ( $\beta 2 \mathrm{~m}$ and I-A $\left.\beta^{\mathrm{b}}\right)$-deficient B6 mice were bred in our facilities and originally obtained from CDTA (Orléans, France). For a description of the genotypes of B10.A and B10.A(2R) mice see the following web-site: http://imgt.cines.fr/textes/IMGTrepertoireMHC/Polymorphism/haplotypes/mouse/MHC/Mu_ haplotypes.html. All experiments involving animals were performed in compliance with the relevant laws and institutional guidelines (INSERM; approval \# 31-13, ethical review \# $\mathrm{MP} / 02 / 32 / 10 / 03)$.

\section{Antibodies}

The following antibodies and secondary reagents were used for phenotypic analysis: FITC, PE-Cy7, Pacific Blue or APC-labeled anti-CD4 (GK1.5), FITC, Alexa Fluor 700 or APClabeled anti-CD8 (53.6.7), PE or APC-labeled anti-CD25 (PC61), anti-HSA-FITC (M1/69), anti-CD69-FITC (H1.2F3), anti-TCR-FITC (H35), anti-Thy1.1-FITC (HIS51), biotin or APClabeled anti-Thy1.2 (53-2-1), anti-Foxp3-PE (FJK-16s), PE-Cy5.5-labelled streptavidine (eBioscience, San Diego, CA). Biotin-conjugated anti-GITR was purchased from R\&D (Lille, France). 


\section{Bone-marrow chimeras}

Bone-marrow from femurs and tibias was collected in DMEM medium supplemented with 10\% FCS. Thy1-expressing cells were eliminated using AT83 (anti-Thy1.1) or HO.22.1.1 (anti-Thy1.1) culture supernatants and rabbit complement (Saxon, HD supplies, Aylesbury, Bucks, UK). Cells from each donor were injected intravenously into lethally $\gamma$-irradiated hosts (8.5 Gy; ${ }^{137} \mathrm{Cs}$ source, $\left.6.3 \mathrm{~Gy} / \mathrm{min}\right)$ that were kept on antibiotic-containing water $(0.2 \%$ of bactrim; Roche, Basel, Switzerland) for the complete duration of the experiment (6 weeks).

\section{Flow cytometry}

Thymocytes, splenocytes or lymph node cells were incubated 30 min on ice in 2.4G2 (anti$\mathrm{Fc} \gamma \mathrm{R} \mathrm{mAb}$ ) hybridoma supernatant also containing $10 \mu \mathrm{g} / \mathrm{mL}$ of $\mathrm{mIgG}$. Cells were then incubated 20 min with saturating concentrations of Abs. Labeled cells were analyzed using a FACSCalibur or an LSRII cytometer and CellQuest (BD Biosciences) or FlowJo (Tree Star, Ashland, OR) software. Intracellular Foxp3-staining was performed according to the instructions of the supplier (eBioscience).

\section{BrdU incorporation studies}

For analysis of kinetics of thymic T cell development, mice were continuously exposed to the thymidine analogue bromodeoxyuridine $(0.8 \mathrm{mg} / \mathrm{mL})$ in their drinking water for various times. Extracellular staining of thymocytes with mAbs against CD4, CD8 and CD25 was performed as described above. Cells were subsequently fixed, permeabilized and stained with FITC-labeled anti-BrdU antibody using the BrdU Flow Kit (BD Pharmingen, Heidelberg, Germany). 


\section{Proliferation assays}

$\mathrm{CD} 4^{+} \mathrm{CD} 25^{+}$and $\mathrm{CD} 4^{+} \mathrm{CD} 25^{-}$splenocytes were enriched as follows. Total splenocytes were treated with antibodies (hybridoma culture supernatants) specific for CD8 (53.6.7), MHC class II (M5/114), Fc $\gamma \mathrm{R}$ (2.4G2), and thus targeted cells eliminated using anti-rat IgG labeled Dynal beads (Dynal, Compiégne, France). Remaining cells were labeled with anti-CD25-PE antibody and subsequently with anti-PE-labeled microbeads, and CD25 $5^{+}$cells were positively selected on a magnetic column (Myltenyi, Paris, France). Remaining CD25 cells were labeled with anti-CD4-FITC, and $\mathrm{CD}^{+}$cells isolated by positive selection using anti-FITC-labeled microbeads. A purity of $\geq 97 \%$ was routinely obtained. $5 \times 10^{4} \mathrm{CD}^{+} \mathrm{T}$ cells were cultured with titrated numbers of $\mathrm{CD} 25^{+}$cells and $5 \times 10^{4}$ irradiated MHC-deficient splenocytes in microtiter plates in presence of soluble anti-CD3 antibody $(2 \mathrm{C} 11,0.5 \mu \mathrm{g} / \mathrm{ml}) .{ }^{3} \mathrm{H}-$ Thymidine was added 3 days later and $16 \mathrm{~h}$ later cells were harvested and ${ }^{3} \mathrm{H}$-Thy incorporation measured.

\section{Microsatellite markers and genotyping}

Genomic DNA was prepared from tail tips using High Pure PCR Template Preparation kit (Roche). Microsatellite markers are referenced in the Mouse Genome Database, release 3.5 (available from www.informatics.jax.org). PCR amplifications were performed in a T3 thermocycler (Biometra, Göttingen, Germany) in $20 \mu \mathrm{L}$ volumes using 100 ng genomic DNA, $0.2 \mu \mathrm{M}$ of each primer (Sigma-Proligo,The Woodlands, TX), 1X PCR reaction buffer (Qbiogen, Illkrich, France), $0.5 \mathrm{U}$ Taq DNA polymerase, $3 \mathrm{mM} \mathrm{MgCl}_{2}, 0.2 \mathrm{mM}$ of each dNTP. The PCR products were size-fractionated on $4 \%$ agarose gels (Resophor, Eurobio, Les Ulis, France) and visualized under UV light after staining with ethidium bromide. 


\section{Statistical analysis}

Statistical significance of the data was analyzed using Student's $t$ test. For correlation analysis, a two-tailed Spearman test was used. $(*: \mathrm{p}<0.05 ; * *$ : $\mathrm{p}<0.01 ; * * *$ : $<<0.001$; NS: non significant). 


\section{Results}

Considerable quantitative differences in the proportion of mature regulatory $T$ cells in the thymus of distinct inbred mouse strains

We have analyzed the percentage of regulatory T cells among $\mathrm{CD}^{+} \mathrm{CD} 8^{-}(\mathrm{CD} 4 \mathrm{SP}) \mathrm{TCR}^{\text {high }}$ thymocytes in B6, C57BR, BALB/c, C3H, CBA, AKR, and B10 mice (Fig. 1). Among CD4SP thymocytes three levels of CD25 can be distinguished: negative, low, and high (Fig. 1A). It has recently been shown that only CD25 ${ }^{\text {high }}$ (but not CD25 $5^{\text {int }}$ ) cells uniformly express Foxp3 and have regulatory capacity $(31,33)$. We therefore calculated the percentage of CD25 $5^{\text {high }}$ cells among CD4SP thymocytes. As shown in figure $1 \mathrm{~B}$ we observed considerable differences between several of these inbred mouse strains.

\section{A locus closely linked to the MHC controls regulatory $T$ cell development in the thymus}

We next investigated the potential implication of the MHC locus in the modulation of CD4SP CD25 $5^{\text {high }}$ thymocyte development (Fig. 2). Congenic B10.BR mice carry the C57BR-derived MHC locus of $\mathrm{H}-2^{\mathrm{k}}$ haplotype on a B10 genetic background. Interestingly, these mice had as high levels of thymic CD4SP CD25 $5^{\text {high }}$ cells as the C57BR donor strain (Fig. 2A), directly implicating an MHC-linked locus in the modulation of thymic regulatory T cell development. We next analyzed the proportion of CD25 $5^{\text {high }}$ cells among CD4SP thymocytes in the congenic BALB.K strain, also carrying an MHC locus of $\mathrm{H}-2^{\mathrm{k}}$ haplotype, but on the BALB/c genetic background. Again, high levels of CD25 $5^{\text {high }}$ cells were found among CD4SP thymocytes (Fig. 2A). Interestingly, the MHC locus carried by BALB.K mice is of $\mathrm{C} 3 \mathrm{H}$ origin, and the latter strain actually has significantly lower percentages of CD25 $5^{\text {high }}$ cells than BALB.K mice (Fig. 2A). This result indicates that the $\mathrm{C} 3 \mathrm{H}$-derived $\mathrm{MHC}$ locus contains a gene allowing for development of high numbers of Treg (in BALB.K mice), and that in $\mathrm{C} 3 \mathrm{H}$ mice non $\mathrm{MHC}$ linked genes neutralize the Treg development-promoting effect of this locus. 
Differences in the proportion of $\mathrm{CD} 25^{\text {high }} \mathrm{CD} 4 \mathrm{SP}$ cells may be caused by differences in development of $\mathrm{CD} 25^{-}$or of $\mathrm{CD} 25^{\text {high }}$ cells. To distinguish between these two possibilities, we calculated the ratio of $\mathrm{CD} 4 \mathrm{SP} \mathrm{CD}_{25}$ and $\mathrm{CD} 25^{\text {high }}$ thymocytes to their $\mathrm{CD}^{+} \mathrm{CD}^{+}$(DP) precursors. The higher percentages of thymic Treg in B10.BR vs. B10 and BALB.K vs. BALB/c mice corresponded to increased Treg/DP ratios, indicating increased differentiation of $\mathrm{CD} 25^{\text {high }}$ cells from DP precursors (Fig. 2B). No differences were observed between the ratios of CD4SP CD25 to DP thymocytes in the mouse strains analyzed (Fig. 2B). Combined, these results indicate that the MHC locus of $\mathrm{H}-2^{\mathrm{k}}$ haplotype contains a gene (or genes) that significantly modulates regulatory $\mathrm{T}$ cell development.

\section{MHC class II molecules are not responsible for the modulation of Treg development}

Potential candidates for genes residing in the MHC locus and modulating thymic Treg development are the MHC class II genes, which are required for Treg differentiation. The potential implication of MHC class II genes was assessed in two different manners.

We first analyzed recombinant congenic mouse lines (Fig. 2C). B10.A mice express I-A and I-E molecules of $\mathrm{H}-2^{\mathrm{k}}$ haplotype and, very interestingly, have high levels of thymic Treg. However, B10.A(2R) mice, that express the same $I-A^{k}$ and $I-E^{k}$ molecules (34), have significantly lower percentages of CD25 $5^{\text {high }}$ cells among CD4SP thymocytes. Therefore, the high levels of thymic Treg in B10.A mice are not due to expression of MHC class II molecules of $\mathrm{H}-2^{\mathrm{k}}$ haplotype.

Secondly, we assessed if the gene(s) responsible for modulation of thymic Treg development act in a thymocyte intrinsic or extrinsic manner (Fig. 3). To this end, we generated radiation bone-marrow chimeras by reconstituting $\mathrm{H}-2^{\text {bk }}$ hosts with a mixture of B6.Thy1.1 and C57BR (Thy1.2) bone marrow. Six weeks later thymocytes were analyzed by flow-cytometry using the Thy 1 allelic marker to distinguish between the two types of donor cells. In these chimeras, 
in which B6 and C57BR thymocytes developed in an identical thymic microenvironment, significantly more CD25 $5^{\text {high }}$ cells developed from C57BR than from B6 precursors (Fig. 3A). Similar results were obtained with single and mixed bone marrow chimeras made using B10.BR and B6 bone marrow (Fig. 3B). These results show that thymocyte-intrinsic factors considerably modulate thymic Treg development. They therefore confirm that MHC class II molecules are not responsible for the distinct percentages of mature thymic Treg observed in the mouse strains studied.

A genetic locus responsible for modulation of thymic Treg development is located in a $\leq 2.2$ Mbp region telomeric to the $M H C$

The data presented here show that an MHC-linked locus contains (a) gene(s) capable of modulating Treg development in the thymus. Our comparison of B10.A and B10.A(2R) congenic mice indicates that a responsible gene must be located in or near the telomeric region of the MHC (34). We wished to more precisely define this region and performed microsatellite analyses of several congenic mouse strains (Table I). As reported previously, B10.A(2R) congenics had lost a telomeric part of the introgressed strain A region in B10.A mice. This region of interest (cf. Fig. 2C), delimited by D17Mit214 and 148, was included in the introgressed regions of B10.BR and BALB.K mice. These data suggest that the "high Treg" phenotype of B10.A, B10.BR, and BALB.K mice may be due to the same gene(s).

We have previously published that Treg development is also quantitatively modulated by non MHC-linked loci (32). In B10.S and B10.D2 congenic strains, decisive genes are located outside the introgressed donor regions. To define if the locus identified in the present report is distinct from those non MHC-linked regions, we performed microsatellite analysis of part of chromosome 17 from B10.S and B10.D2 mice (Table I). B10.S and B10.D2 mice, which have a B10 "low Treg" phenotype (32), have donor (SJL and DBA/2, respectively) strain-derived 
D17Mit214 to 148 locus. Moreover, the introgressed DBA/2 region in B10.D2 mice completely overlaps the introgressed $\mathrm{C} 3 \mathrm{H}$ region in BALB.K mice. These data unequivocally demonstrate that the genetic loci responsible for the quantitative thymic Treg phenotypes reported here and in our previous publication (32) are, at least in part, different.

\section{Distinct levels of thymic Treg are caused by differences in their intrathymic differentiation} Upon their differentiation, fully mature CD25 and CD25+ CD4SP thymocytes remain in the thymus for approximately two weeks (ref. (35) and data not shown). Higher levels of CD25 ${ }^{\text {high }}$ thymocytes may therefore be caused by prolonged retention time in the thymus, or to increased differentiation of these cells. To assess the latter possibility, we fed B6 and B10.BR mice with the nucleotide analog BrdU in their drinking water for various periods of time, and analyzed the appearance of BrdU-labeled Treg (Fig. 4). More BrdU ${ }^{+} \mathrm{CD} 25^{\text {high }}$ cells were found among B10.BR than among B6 CD4SP thymocytes, while no difference was found for CD4SP CD25 cells (Fig. 4). These data show that the difference in the proportion of CD25 ${ }^{\text {high }}$ cells among CD4SP thymocytes is at least in part due to differences in their differentiation. However, formally we cannot exclude the possibility that a difference in thymic retention of Treg also plays a role.

Regulatory $T$ lymphocytes from low and high producer strains are phenotypically and functionally equivalent

We next investigated if the mature CD4SP CD25 thymocytes developing in the distinct mouse strains were identical. Flow-cytometry analysis revealed that the phenotype of mature regulatory T cells in B6, B10.BR, and C57BR mice was identical (Fig. 5A). HSA is expressed at high levels on immature thymocytes and downmodulated at the mature CD4SP stage of development. In contrast to their $\mathrm{CD}^{-} 5^{-}$and $\mathrm{CD} 25^{\text {int }}$ counterparts, which are in majority 
HSA $^{\text {high }}$, CD25 $5^{\text {high }}$ CD4SP thymocytes all express relatively low levels of HSA. CD69 is an early activation marker that is upregulated during thymic positive selection and downmodulated when thymocytes have reached the CD4SP stage of development. While most $\mathrm{CD} 25^{-}$and $\mathrm{CD} 25^{\text {int }} \mathrm{CD} 4 \mathrm{SP}$ cells are $\mathrm{CD} 69^{\text {high }}$, practically all $\mathrm{CD} 25^{\text {high }} \mathrm{CD} 4 \mathrm{SP}$ thymocytes are CD69 $9^{\text {low }}$. GITR is a marker highly expressed by Treg and at lower levels by conventional $\mathrm{T}$ lymphocytes. The phenotype of these three markers, allowing for a clear distinction between regulatory and conventional $\mathrm{T}$ cells, was identical for B6, B10.BR, and C57BR CD25 $5^{\text {high }}$ CD4SP thymocytes.

Probably the best marker for Treg is the transcription factor Foxp3 (24-26,30,31). We therefore also analyzed expression of this protein in B6 and B10.BR CD4SP thymocytes. As shown in figure $5 \mathrm{~B}$ similar high levels of Foxp3 were observed in CD4SP CD2 $5^{\text {high }}$ thymocytes in these two mouse strains.

We next analyzed the immunomodulatory effector function of B6 and B10.BR derived $\mathrm{CD} 4^{+} \mathrm{CD} 25^{\text {high }} \mathrm{T}$ lymphocytes (Fig. $5 \mathrm{C}$ ). Using an in vitro $\mathrm{T}$ cell proliferation-inhibition assay, we observed that regulatory $\mathrm{T}$ cells from the high and low producer strains B10.BR and B6, respectively, were similarly effective. Combined, these data show that the $\mathrm{CD} 4^{+} \mathrm{CD} 25^{\text {high }}$ cells developing in the distinct mouse strains analyzed represent genuine Treg and not some other CD25 $5^{\text {high }}$ population (e.g. activated conventional T cells).

Thymocyte-intrinsic factors modulate development of Foxp $3^{+}$Treg

Regulatory $\mathrm{T}$ lymphocytes are predominantly, but not exclusively, $\mathrm{CD} 25^{\text {high }}$. The very best marker for Treg is Foxp3 and we therefore assessed if the genetic difference in Treg development holds true if these cells are defined as those expressing this transcription factor (Fig. 6). Mixed bone marrow chimeras were generated by reconstituting lethally irradiated hosts with a mixture of B6.Thy1.1 and B10.BR (Thy1.2) bone marrow. Six weeks later 
thymocytes from these chimeras were analyzed using the allelic Thy1 marker to distinguish between the two types of donor bone marrow injected. As shown in figure 6, substantially more Foxp $3^{+}$CD4SP thymocytes were observed among B10.BR than among B6 thymocytes. Since no markers are available to distinguish between BALB/c and BALB.K CD4SP thymocytes, we generated two types of bone marrow chimeras. Lethally irradiated hosts were reconstituted with B6.Thy1.1 plus BALB/c or BALB.K (Thy1.2) bone marrow. Thymocytes from these chimeras were analyzed six weeks later. In both types of chimeras identical percentages of Foxp3 ${ }^{+}$CD4SP cells among B6 thymocytes were found (Fig. 6). BALB.K thymocytes contained substantially more Foxp $3^{+}$CD4SP Treg than BALB/c thymocytes. These data show that development of Foxp $3^{+}$regulatory $\mathrm{T}$ lymphocytes is modulated by polymorphic genes linked to the MHC locus.

The percentages of thymic and peripheral Foxp $3^{+}$Treg in distinct mouse strains are directly correlated.

We next investigated if the percentages of Foxp $3^{+}$CD4SP thymocytes are correlated to those found in lymph nodes and spleen. The percentages of $\mathrm{CD}^{+} \mathrm{CD} 8^{-} \mathrm{TCR}^{\text {high }} \mathrm{Foxp}^{+}$cells among $\mathrm{CD}^{+} \mathrm{CD} 8{ }^{-} \mathrm{TCR}^{\text {high }}$ thymocytes, splenocytes, and lymph node cells from $\mathrm{B} 6+\mathrm{B} 10 . \mathrm{BR} \rightarrow$ $\mathrm{B} 6 \mathrm{CBAF} 1, \mathrm{~B} 6+\mathrm{BALB} / \mathrm{c} \rightarrow \mathrm{B} 6 \mathrm{D} 2 \mathrm{~F} 1$, and $\mathrm{B} 6+\mathrm{BALB} / \mathrm{K} \rightarrow \mathrm{B} 6 \mathrm{CBAF} 1$ mixed bone marrow chimeras were analyzed by flow cytometry. As shown in figure 7, a statistically significant correlation between thymic and peripheral levels of Foxp $3^{+}$cells was found. No statistically significant correlation between thymic and peripheral Treg was observed when Treg were defined as CD25 $5^{\text {high }}$ cells (data not shown). 


\section{Discussion}

In this report, we showed that genetic factors modulate thymic development of regulatory $\mathrm{T}$ cells in a quantitatively very substantial fashion. Responsible genes act in a thymocyteintrinsic manner and modulate the differentiation of Treg from their immature precursors. Importantly, we mapped the locus involved to a $\leq 2.2 \mathrm{Mbp}$ region telomeric to the MHC, definitively excluding a role for MHC class II genes.

Our data indicate that MHC-linked genes very substantially modulate thymic differentiation of $\mathrm{CD}^{+}{ }^{+} \mathrm{CD} 25^{+} \mathrm{Foxp}^{+}$regulatory $\mathrm{T}$ cells. We have previously reported that also non MHClinked loci modulate Treg development, although in a quantitatively much less impressive manner (32). Importantly, using microsatellite analysis of the precise donor-regions introgressed into the distinct congenic mouse-strains used in the present and our previously published reports, we here firmly establish that Treg development is quantitatively controlled by multiple loci. Interestingly, BALB.K mice have a high percentage of Treg, in contrast to both the MHC-donor $(\mathrm{C} 3 \mathrm{H})$ and acceptor $(\mathrm{BALB} / \mathrm{c})$ mouse-strains. This observation indicates that (a) non-MHC linked gene(s) inhibit(s) the Treg-differentiation promoting activity of an MHC-linked gene in $\mathrm{C} 3 \mathrm{H}$ mice, and again confirms that multiple genes modulate Treg development. Only a single other example for genetic control of Treg development is currently known. Mutations in the gene encoding the forkhead/winged helix transcription factor Foxp3 lead to a complete absence of $\mathrm{CD} 4^{+} \mathrm{CD} 25^{+}$regulatory $\mathrm{T}$ cell development in mice. However, no subtler genetically controlled effects on regulatory $\mathrm{T}$ cell development were previously known.

At least three of the studied mouse strains (C3H, CBA, and B10.BR) carrying an MHC-linked gene allowing for development of high numbers of Treg are reference models for Experimental Autoimmune Thyroiditis $(36,37)$. Since levels of thymic and peripheral Foxp3 ${ }^{+}$ Treg are directly correlated, it is tempting to speculate that the responsible gene would 
somehow be involved in susceptibility to autoimmunity. However, $\mathrm{C} 3 \mathrm{H}$ mice also carry another gene that inhibits expression of the thymic phenotype of the MHC-linked gene. Therefore, we do not think that the responsible gene would affect susceptibility to autoimmune disease for simple quantitative reasons. Rather, since it acts in a $\mathrm{T}$ cell-intrinsic manner, the responsible gene could somehow influence peripheral function of Treg, e.g. by affecting TCR-repertoire, homing, adhesion, or TCR-signal transduction. Identification of such differences will first require identification of the responsible gene(s) and then generation and extensive analysis of genetically modified mice. It will also be of considerable interest to study Treg development in other mouse-models for autoimmune-disease.

Here we showed that percentages of thymic and peripheral Foxp $3^{+}$Treg were directly correlated. In contrast, levels of thymic and peripheral CD25 $5^{\text {high }}$ Treg did not correlate. This observation is, at least in part, explained by our observation that substantial differences exist between the fraction of Foxp $3^{+}$cells expressing high levels of CD25 in the thymus and the periphery (not shown). CD25-expression by Treg has previously been shown to be unstable in vivo (38). It will be of interest to study the factors determining CD25-expression by Treg in vivo.

Identification of the responsible gene(s) will also be important to study regulatory $\mathrm{T}$ cell development in the thymus. It is currently unknown how and when during development $\mathrm{T}$ cell precursors commit to the Foxp $3^{+}$regulatory T cell lineage. As discussed in the introduction, it remains unclear if high affinity recognition of $\mathrm{MHC}$ /peptide ligands by immature precursors commits these cells to the Treg lineage $(13,15,20-22)$. Identification of the gene(s) involved in the quantitative modulation of Treg differentiation described here, and the processes in which they are involved, should open new avenues for the study of the still enigmatic process of regulatory $\mathrm{T}$ cell development. 


\section{Acknowledgements}

We thank the staff of the IFR 30 animal facility, and in particular Maryline Calise, for expert animal husbandry. We also gratefully acknowledge Drs. Gilbert Fournié and Jean-Charles Guéry for critical reading of the manuscript. 
Abbreviations used in this paper:

B6, C57BL/6

B10, C57BL/10

$\mathrm{DP}, \mathrm{CD} 4^{+} \mathrm{CD} 8^{+}$

$\mathrm{CD} 4 \mathrm{SP}, \mathrm{CD}^{+} \mathrm{CD}^{-}$

Treg, regulatory $\mathrm{T}$ cell 


\section{References}

1 Waldmann, H., Chen, T. C., Graca, L., Adams, E., Daley, S., Cobbold, S., and Fairchild, P. J. 2006. Regulatory T cells in transplantation. Sem. Immunol. 18:111-9.

2 Sakaguchi, S. 2004. Naturally arising CD4+ regulatory T cells for immunologic selftolerance and negative control of immune responses. Annu. Rev. Immunol. 22:531-62.

3 Piccirillo, C. A. and Shevach, E. M. 2004. Naturally-occurring CD4+CD25+ immunoregulatory T cells: central players in the arena of peripheral tolerance. Sem. Immunol. 16:81-8.

4 Coombes, J. L., Robinson, N. J., Maloy, K. J., Uhlig, H. H., and Powrie, F. 2005. Regulatory T cells and intestinal homeostasis. Immunol. Rev. 204:184-94.

5 Joffre, O., Gorsse, N., Romagnoli, P., Hudrisier, D., and van Meerwijk, J. P. 2004. Induction of antigen-specific tolerance to bone marrow allografts with CD4+CD25+ T lymphocytes. Blood 103:4216-21.

6 Joffre, O. and van Meerwijk, J. P. M. 2006. CD4+CD25+ regulatory T lymphocytes in bone marrow transplantation. Sem. Immunol. 18:128-135.

7 Asano, M., Toda, M., Sakaguchi, N., and Sakaguchi, S. 1996. Autoimmune disease as a consequence of developmental abnormality of a T cell subpopulation. J. Exp. Med. 184:387-96.

8 Bensinger, S. J., Bandeira, A., Jordan, M. S., Caton, A. J., and Laufer, T. M. 2001. Major Histocompatibility Complex Class II-positive Cortical Epithelium Mediates the Selection of CD4+25+ Immunoregulatory T Cells. J. Exp. Med. 194:427-438.

9 Romagnoli, P., Hudrisier, D., and van Meerwijk, J. P. M. 2002. Preferential recognition of self-antigens despite normal thymic deletion of CD4+CD25+ regulatory T cells. J. Immunol. 168:1644-1648.

10 Pacholczyk, R., Kraj, P., and Ignatowicz, L. 2002. Peptide specificity of thymic selection of CD4+CD25+ T cells. J. Immunol. 168:613-20.

11 Fisson, S., Darrasse-Jeze, G., Litvinova, E., Septier, F., Klatzmann, D., Liblau, R., and Salomon, B. L. 2003. Continuous Activation of Autoreactive CD4+ CD25+ Regulatory T Cells in the Steady State. J. Exp. Med. 198:737-746.

12 Hsieh, C. S., Liang, Y., Tyznik, A. J., Self, S. G., Liggitt, D., and Rudensky, A. Y. 2004. Recognition of the peripheral self by naturally arising CD25+ CD4+ T cell receptors. Immunity 21:267-77.

13 van Santen, H.-M., Benoist, C., and Mathis, D. 2004. Number of T Reg Cells That Differentiate Does Not Increase upon Encounter of Agonist Ligand on Thymic Epithelial Cells. J. Exp. Med. 200:1221-1230.

14 Romagnoli, P., Hudrisier, D., and van Meerwijk, J. P. M. 2005. Molecular signature of recent thymic selection events on effector and regulatory CD4+ T lymphocytes. $J$. Immunol. 175:5751-5758.

15 Ribot, J., Romagnoli, P., and van Meerwijk, J. P. 2006. Agonist Ligands Expressed by Thymic Epithelium Enhance Positive Selection of Regulatory T Lymphocytes from Precursors with a Normally Diverse TCR Repertoire. J. Immunol. 177:1101-7.

16 Hori, S., Haury, M., Lafaille, J. J., Demengeot, J., and Coutinho, A. 2002. Peripheral expansion of thymus-derived regulatory cells in anti-myelin basic protein $\mathrm{T}$ cell receptor transgenic mice. Eur. J. Immunol. 32:3729-3735. 
17 Walker, L. S. K., Chodos, A., Eggena, M., Dooms, H., and Abbas, A. K. 2003. Antigen-dependent Proliferation of CD4+ CD25+ Regulatory T Cells In Vivo. J. Exp. Med. 198:249-258.

18 Cozzo, C., Larkin, J., III, and Caton, A. J. 2003. Cutting Edge: Self-Peptides Drive the Peripheral Expansion of CD4+CD25+ Regulatory T Cells. J. Immunol. 171:56785682.

19 Samy, E. T., Parker, L. A., Sharp, C. P., and Tung, K. S. 2005. Continuous control of autoimmune disease by antigen-dependent polyclonal CD4+CD25+ regulatory $\mathrm{T}$ cells in the regional lymph node. J. Exp. Med. 202:771-81.

20 Jordan, M. S., Boesteanu, A., Reed, A. J., Petrone, A. L., Holenbeck, A. E., Lerman, M. A., Naji, A., and Caton, A. J. 2001. Thymic selection of CD4+CD25+ regulatory T cells induced by an agonist self-peptide. Nat. Immunol. 2:301-6.

21 Kawahata, K., Misaki, Y., Yamauchi, M., Tsunekawa, S., Setoguchi, K., Miyazaki, J.i., and Yamamoto, K. 2002. Generation of CD4+CD25+ Regulatory T Cells from Autoreactive T Cells Simultaneously with Their Negative Selection in the Thymus and from Nonautoreactive $\mathrm{T}$ Cells by Endogenous TCR Expression. J. Immunol. 168:4399-4405.

22 Apostolou, I., Sarukhan, A., Klein, L., and von Boehmer, H. 2002. Origin of regulatory $\mathrm{T}$ cells with known specificity for antigen. Nat. Immunol. 3:756-63.

23 D'Cruz, L. M. and Klein, L. 2005. Development and function of agonist-induced CD25+Foxp3+ regulatory $\mathrm{T}$ cells in the absence of interleukin 2 signaling. Nat. Immunol. 6:1152-9.

24 Fontenot, J. D., Gavin, M. A., and Rudensky, A. Y. 2003. Foxp3 programs the development and function of CD4(+)CD25(+) regulatory T cells. Nat. Immunol. 3:3.

25 Hori, S., Nomura, T., and Sakaguchi, S. 2003. Control of regulatory $\mathrm{T}$ cell development by the transcription factor Foxp3. Science 299:1057-61.

26 Khattri, R., Cox, T., Yasayko, S. A., and Ramsdell, F. 2003. An essential role for Scurfin in CD4(+)CD25(+) T regulatory cells. Nat. Immunol. 3:3.

27 Bennett, C. L., Christie, J., Ramsdell, F., Brunkow, M. E., Ferguson, P. J., Whitesell, L., Kelly, T. E., Saulsbury, F. T., Chance, P. F., and Ochs, H. D. 2001. The immune dysregulation, polyendocrinopathy, enteropathy, X-linked syndrome (IPEX) is caused by mutations of FOXP3. Nat. Genet. 27:20-1.

28 Brunkow, M. E., Jeffery, E. W., Hjerrild, K. A., Paeper, B., Clark, L. B., Yasayko, S. A., Wilkinson, J. E., Galas, D., Ziegler, S. F., and Ramsdell, F. 2001. Disruption of a new forkhead/winged-helix protein, scurfin, results in the fatal lymphoproliferative disorder of the scurfy mouse. Nat. Genet. 27:68-73.

29 Wildin, R. S., Ramsdell, F., Peake, J., Faravelli, F., Casanova, J. L., Buist, N., LevyLahad, E., Mazzella, M., Goulet, O., Perroni, L., Bricarelli, F. D., Byrne, G., McEuen, M., Proll, S., Appleby, M., and Brunkow, M. E. 2001. X-linked neonatal diabetes mellitus, enteropathy and endocrinopathy syndrome is the human equivalent of mouse scurfy. Nat. Genet. 27:18-20.

30 Yagi, H., Nomura, T., Nakamura, K., Yamazaki, S., Kitawaki, T., Hori, S., Maeda, M., Onodera, M., Uchiyama, T., Fujii, S., and Sakaguchi, S. 2004. Crucial role of FOXP3 in the development and function of human CD25+CD4+ regulatory $\mathrm{T}$ cells. Int. Immunol. 16:1643-56.

31 Fontenot, J. D., Rasmussen, J. P., Williams, L. M., Dooley, J. L., Farr, A. G., and Rudensky, A. Y. 2005. Regulatory T cell lineage specification by the forkhead transcription factor foxp3. Immunity 22:329-41. 
32 Romagnoli, P., Tellier, J., and van Meerwijk, J. P. M. 2005. Genetic control of thymic development of CD4+CD25+FoxP3+ regulatory T lymphocytes. Eur. J. Immunol. 35:3525-3532.

33 Setoguchi, R., Hori, S., Takahashi, T., and Sakaguchi, S. 2005. Homeostatic maintenance of natural Foxp3(+) CD25(+) CD4(+) regulatory T cells by interleukin (IL)-2 and induction of autoimmune disease by IL-2 neutralization. J. Exp. Med. 201:723-35.

34 Klein, J., Figueroa, F., and David, C. S. 1983. H-2 haplotypes, genes and antigens: second listing. II. The H-2 complex. Immunogen. 17:553-96.

35 Egerton, M., Scollay, R., and Shortman, K. 1990. Kinetics of mature T-cell development in the thymus. Proc. Natl. Acad. Sci. U.S.A. 87:2579-82.

36 Vladutiu, A. O. and Rose, N. R. 1971. Autoimmune murine thyroiditis relation to histocompatibility (H-2) type. Science 174:1137-9.

37 Kong, Y., David, C. S., Giraldo, A. A., Elrehewy, M., and Rose, N. R. 1979. Regulation of autoimmune response to mouse thyroglobulin: influence of H-2D-end genes. J. Immunol. 123:15-8.

38 Zelenay, S., Lopes-Carvalho, T., Caramalho, I., Moraes-Fontes, M. F., Rebelo, M., and Demengeot, J. 2005. Foxp3+ CD25- CD4 T cells constitute a reservoir of committed regulatory cells that regain CD25 expression upon homeostatic expansion. Proc. Natl. Acad. Sci. U.S.A. 102:4091-6. 


\section{Legends to the figures}

\section{Figure 1.}

Distinct proportions of $C D 25^{\text {high }}$ regulatory $T$ cells in the thymus of various inbred mouse strains.

(A) Freshly isolated thymocytes were analyzed by 4-color flow cytometry for expression of CD4, CD8, CD25 and TCR. Used electronic gates are indicated in the figure. (B) Percentages of $\mathrm{CD} 25^{\text {high }}$ cells among $\mathrm{CD} 4^{+} \mathrm{CD} 8^{-} \mathrm{TCR}^{\text {high }}$ thymocytes calculated using gates indicated in $\mathrm{A}$. Mean values $( \pm S D)$ are shown $(n \geq 5) .{ }^{*} p<0.05,{ }^{*} * p<0.001$, NS: not significant, Student's ttest.

\section{Figure 2.}

The locus responsible for modulation of Treg-development is closely linked to the MHC.

(A) Thymocytes from indicated mouse strains were analyzed by 4-color flow cytometry. Mean values $( \pm \mathrm{SD})$ of the percentages of $\mathrm{CD}_{2} 5^{\text {high }}$ cells among $\mathrm{CD}^{+} \mathrm{CD} 8^{-} \mathrm{TCR}^{\text {high }}$ thymocytes are shown $(\mathrm{n} \geq 5)$. (B) Ratios of CD25 $5^{\text {high }}$ (upper panels) or CD25- (lower panels) $\mathrm{CD}^{+} \mathrm{CD} 8^{-} \mathrm{TCR}^{\text {high }}$ to $\mathrm{CD} 4^{+} \mathrm{CD} 8^{+}$thymocytes in indicated mouse strains. Depicted are mean values $\pm \operatorname{SD}(n \geq 5)$. (C) Thymocytes were analyzed by 4-color flow cytometry. Mean values $( \pm \mathrm{SD})$ of the percentages of $\mathrm{CD} 25^{\text {high }}$ cells among $\mathrm{CD}^{+} \mathrm{CD} 8^{-} \mathrm{TCR}^{\text {high }}$ thymocytes are shown $(\mathrm{n}=5) . * * \mathrm{p}<0.01, * * * \mathrm{p}<0.001$, Student's t-test.

\section{Figure 3.}

A thymocyte-intrinsic mechanism causes distinct proportions of CD25 $5^{\text {high }}$ Treg.

(A) Lethally irradiated $\mathrm{H}-2^{\mathrm{bk}}$ (B6CBAF1, $\mathrm{n}=3$ or $\left.(\mathrm{B} 6 \mathrm{xB} 10 . \mathrm{BR}) \mathrm{F} 1, \mathrm{n}=3\right)$ hosts were reconstituted with bone marrow from B6.Thy1.1 and C57BR mice (Thy1.2) at a ratio of 1:1. 
Six weeks later, thymocytes were analyzed by 4-color flow cytometry for expression of CD4, CD8, CD25 and Thy1.1 or Thy1.2. Cells were electronically gated using indicated gates. Bar graphs depict mean values $( \pm \mathrm{SD})$ of the percentage of $\mathrm{CD} 25^{\text {high }}$ cells among $\mathrm{CD} 4^{+} \mathrm{CD} 8^{-}$ Thy $1.1^{+}$or Thy $1.2^{+}$thymocytes. (B) B6.Thy $1.1+\mathrm{B} 10 . \mathrm{BR} \rightarrow(\mathrm{B} 6 \times \mathrm{B} 10 . \mathrm{BR}) \mathrm{F}_{1}(\mathrm{n}=5), \mathrm{B} 10 . \mathrm{BR}$ $\rightarrow(\mathrm{B} 6 \times \mathrm{B} 10 . \mathrm{BR}) \mathrm{F}_{1}(\mathrm{n}=5)$, and $\mathrm{B} 6 \rightarrow(\mathrm{B} 6 \times \mathrm{B} 10 . \mathrm{BR}) \mathrm{F}_{1}(\mathrm{n}=5)$ bone-marrow chimeras were analyzed as in $\mathrm{A}(\mathrm{n} \geq 7) . * * * \mathrm{p}<0.001$, Student's t-test.

\section{Figure 4.}

Distinct levels of $C D 25^{\text {high }}$ regulatory $T$ cells differentiate in thymi of B6 and B10.BR mice.

BrdU was administrated to mice in their drinking water continuously. Thymocytes were analyzed at indicated timepoints by 4-color flow cytometry. Indicated are the percentages of $\mathrm{CD} 25^{\text {high }} \mathrm{BrdU}^{+}$(left hand panel) and $\mathrm{CD}^{2} 5^{-} \mathrm{BrdU}^{+}$(right hand panel) cells among $\mathrm{CD}^{+} \mathrm{CD}^{-}$ B6 and B10.BR (as indicated) thymocytes. ${ }^{*} \mathrm{p}<0.05,{ }^{*} \mathrm{p}<0.01(\mathrm{n}=3)$, Student's t-test.

\section{Figure 5.}

$C D 4^{+} C D 25^{\text {high }}$ Treg from low and high producer strains are phenotypically and functionally identical.

(A) Thymocytes from indicated mouse strains were analyzed by 4-color flow-cytometry. Electronically gated $\mathrm{CD} 4^{+} \mathrm{CD} 8^{-}$cells were analyzed for expression of the indicated surface markers. (B) Electronically gated $\mathrm{CD}^{+} \mathrm{CD} 8^{-}$thymocytes from indicated mouse strains were analyzed for $\mathrm{CD} 25$ and intracellular FoxP3 expression by flow-cytometry. (C) $\mathrm{CD}^{+} \mathrm{CD} 25^{-}$ splenic conventional T cells (Teff) from B6 or B10.BR mice were stimulated with anti-CD3 antibody and MHC-deficient APC in presence of B6 ( $\square)$ or B10.BR ( $\square$ ) Treg at indicated ratios, and proliferation assessed by ${ }^{3} \mathrm{H}$-Thy incorporation. A representative of three independent experiments with similar results is shown. 


\section{Figure 6.}

A thymocyte-intrinsic mechanism causes development of distinct proportions of Foxp ${ }^{+}$Treg. Lethally irradiated B6CBAF1 $\left(\mathrm{H}-2^{\mathrm{bk}}\right)$ or B6D2F1 $\left(\mathrm{H}-2^{\text {bd }}\right)$ hosts $(\mathrm{n}=5$ for each) were reconstituted with a mixture of bone marrow cells at a ratio of 1:1 from B6.Thy1.1 and either B10.BR (Thy1.2), BALB/c (Thy1.2) or BALB.K (Thy1.2) mice. Six weeks later, thymocytes were analyzed by 4-color flow cytometry for expression of CD4, CD8, Foxp3 (isotype matched control in grey shading), Thy1.1 and Thy1.2. Cells were electronically gated as indicated and the percentage of Foxp $3^{+}$cells among CD4SP Thy $1.1^{+}$or CD4SP Thy $1.2^{+}$cells was calculated. Bar graphs depict mean values $( \pm \mathrm{SD}) .{ }^{* * *} \mathrm{p}<0.001$, Student's t-test.

\section{Figure 7.}

Direct correlation between levels of thymic and peripheral Foxp $3^{+}$Treg.

Thymocytes, splenocytes and LN cells from the hematopoietic chimeras shown in Fig. 6 were stained with anti-CD4, anti-CD8, anti-Foxp3, anti-Thy1.1 and anti-Thy1.2 Ab and analyzed by flow cytometry. The percentage of $\mathrm{Foxp}^{+}$cells among $\mathrm{CD} 4^{+} \mathrm{CD} 8$ cells of B6 $(\diamond)$, B10.BR $(\square)$, BALB/c $(\bigcirc)$ or BALB.K $(\times)$ origin was calculated. A statistically significant correlation (Spearman test) exists between thymocyte and splenocyte values $(\mathrm{p}<0.001)$ on one hand (A), and thymocyte and LN cell ones $(\mathrm{p}<0.05)$ on the other $(\mathrm{B})$. 
Figure 1

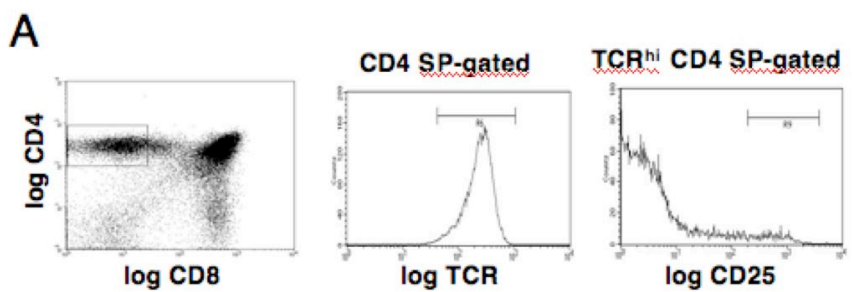

B

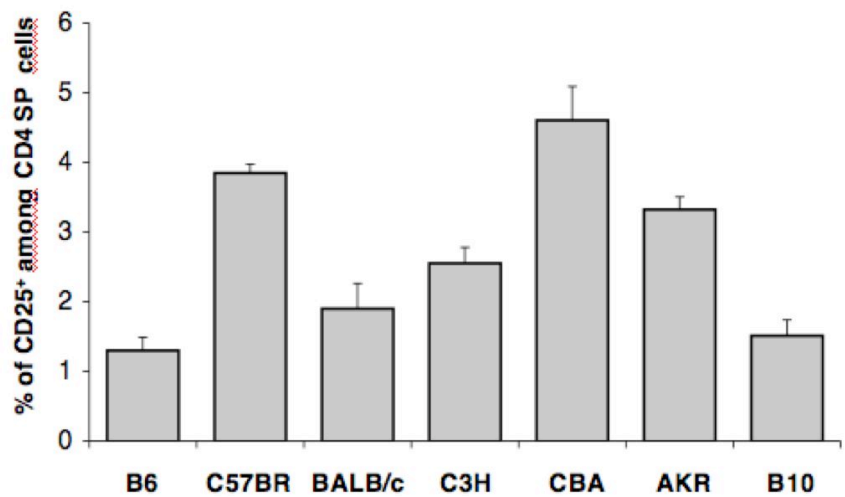

\begin{tabular}{|c|c|c|c|c|c|c|}
\cline { 2 - 7 } \multicolumn{1}{c|}{} & C57BR & BALB/c & C3H & CBA & AKR & B10 \\
\hline B6 & $\star \star \star$ & $\star \star \star$ & $\star \star \star$ & $\star \star \star$ & $\star \star \star$ & NS \\
\hline C57BR & & $\star \star \star$ & $\star \star \star$ & $\star$ & $\star \star \star$ & $\star \star \star$ \\
\hline BALB/C & \multicolumn{9}{|c}{} & $\star$ & $\star \star \star$ & $\star \star \star$ & $\star \star \star$ \\
\hline C3H & \multicolumn{3}{|c}{} & $\star \star \star$ & $\star \star \star$ \\
\hline CBA & \multicolumn{3}{|c}{} & $\star \star \star$ \\
\hline AKR & \multicolumn{3}{|c}{} \\
\hline
\end{tabular}



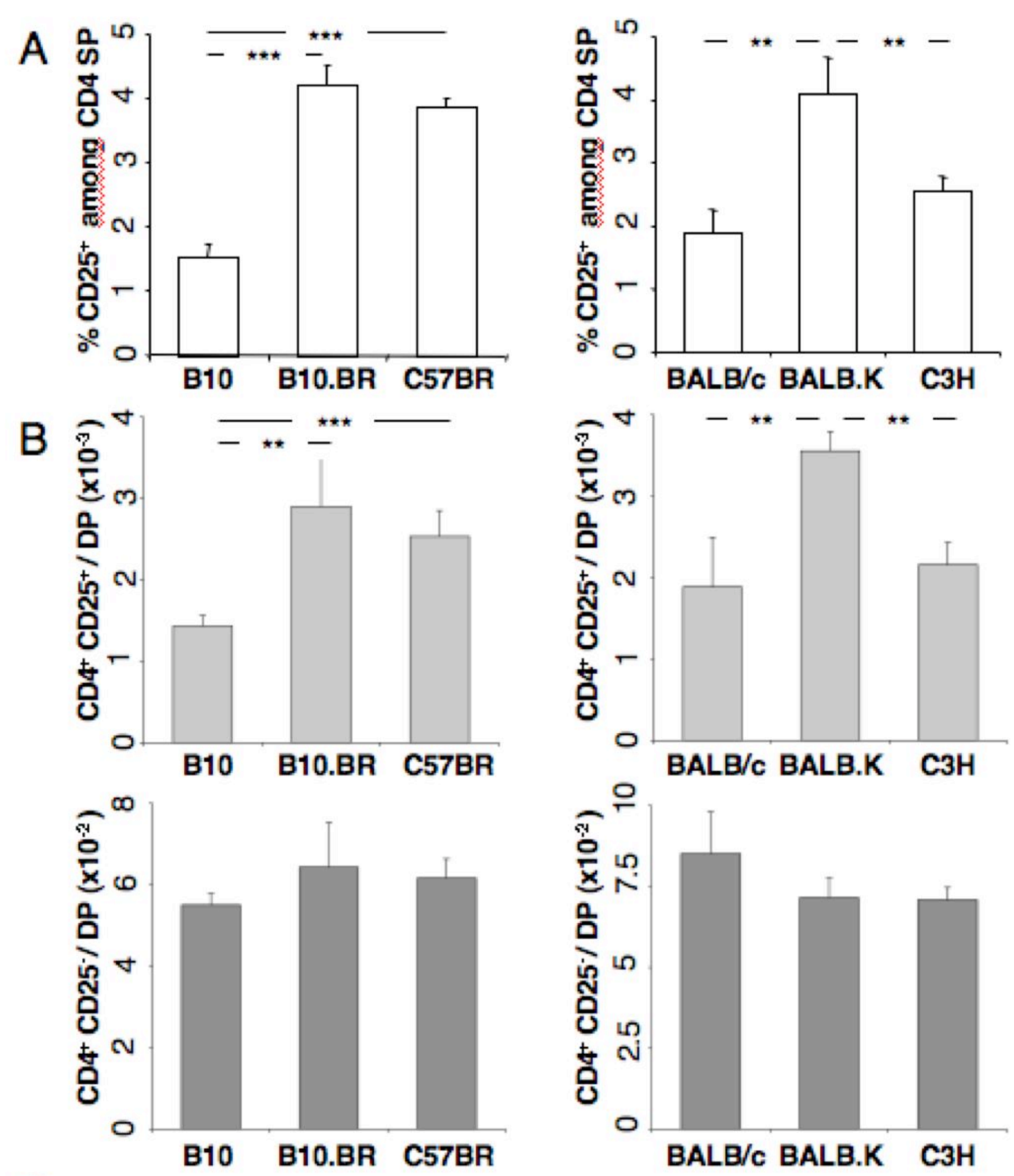

C

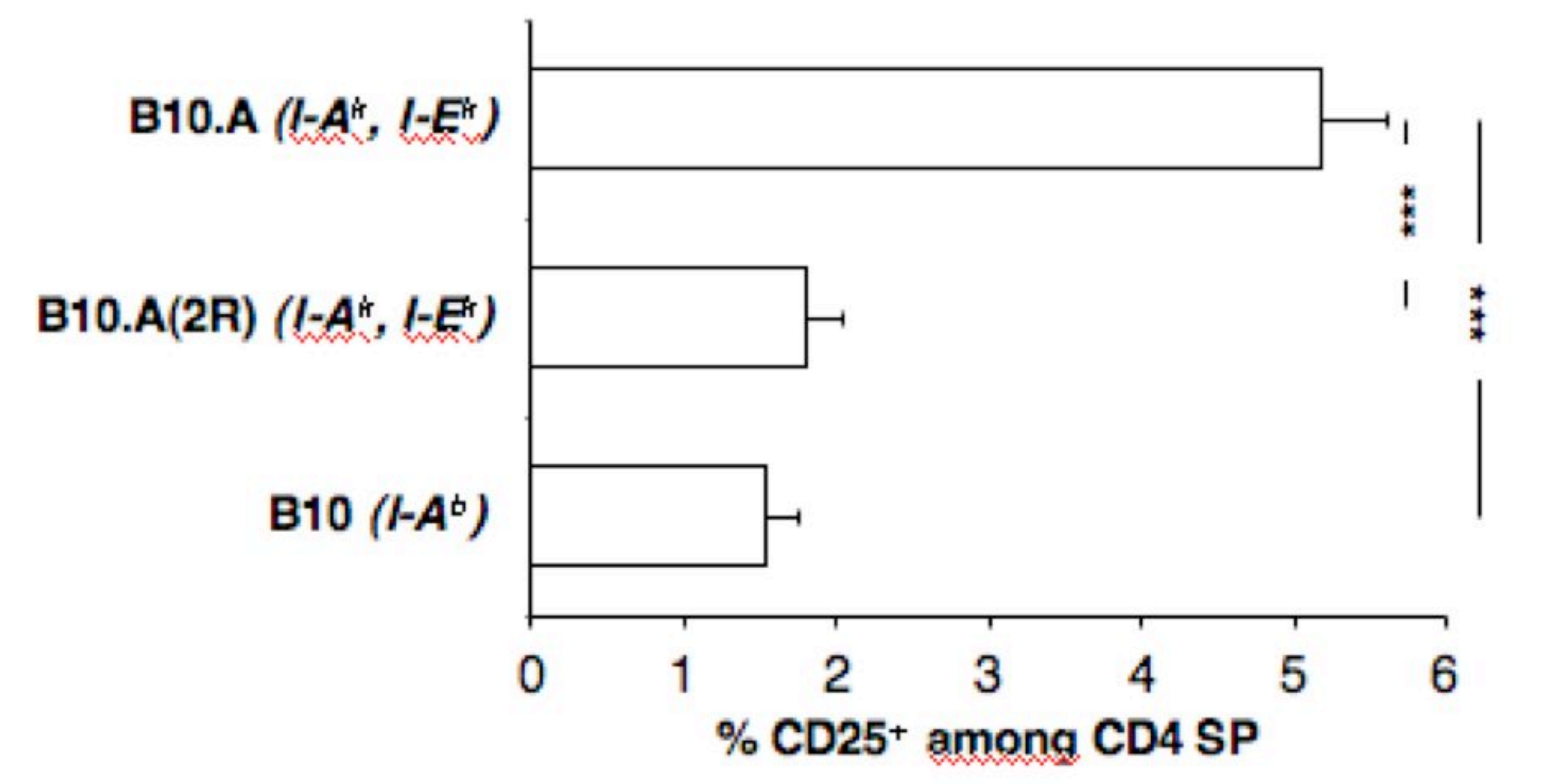


Figure 3

A

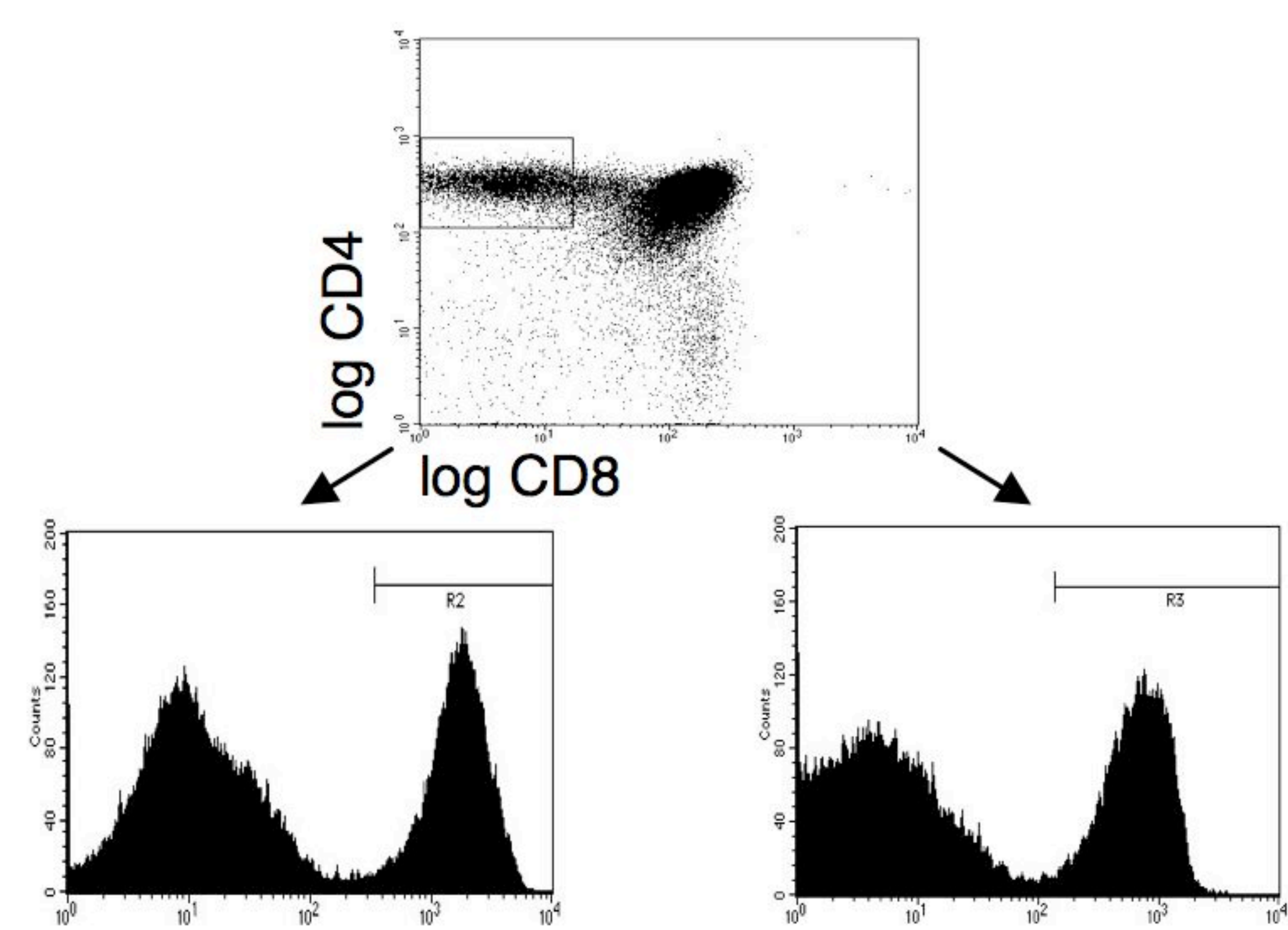

log Thy1.

log Thy1.2

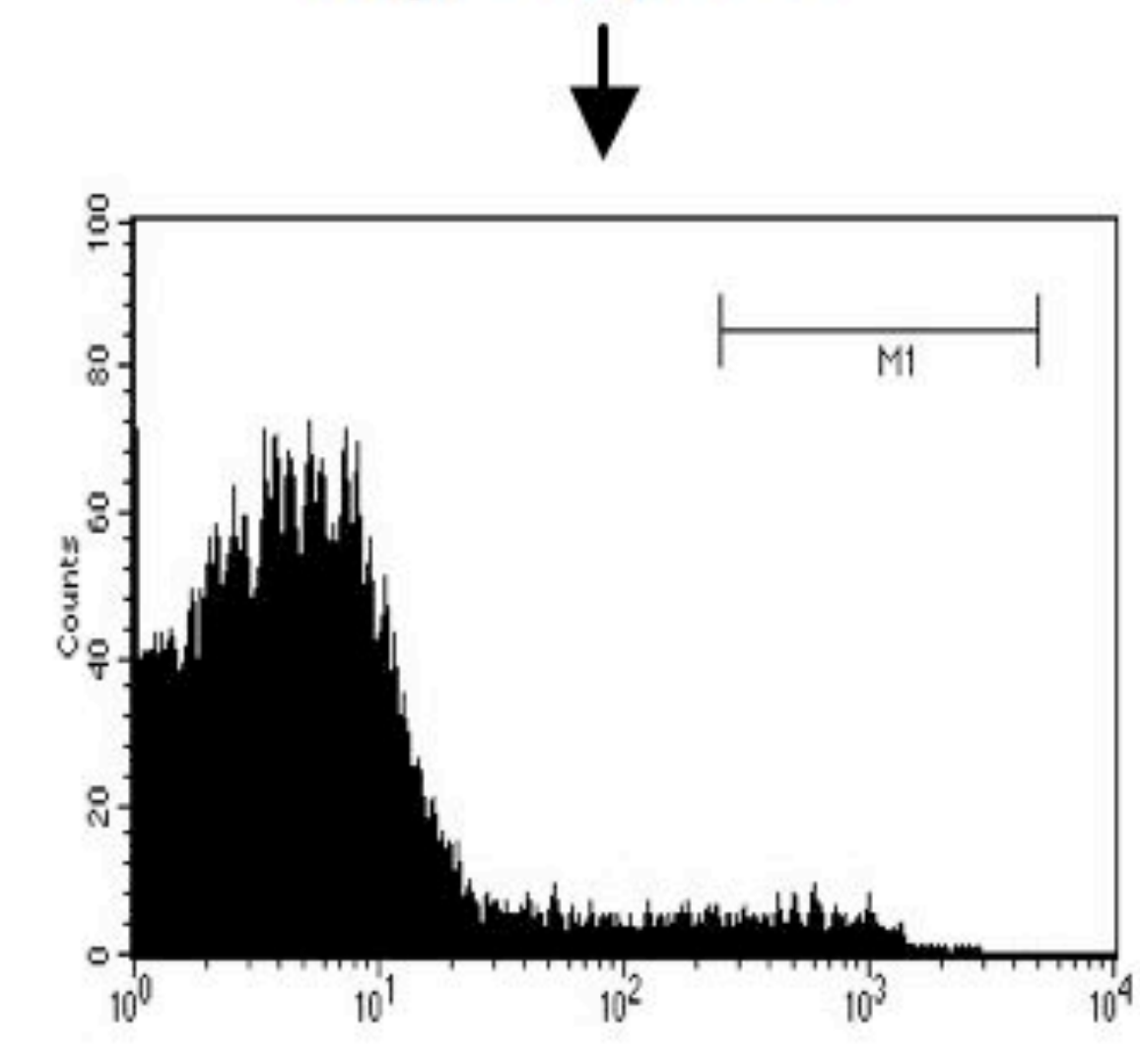

log CD25

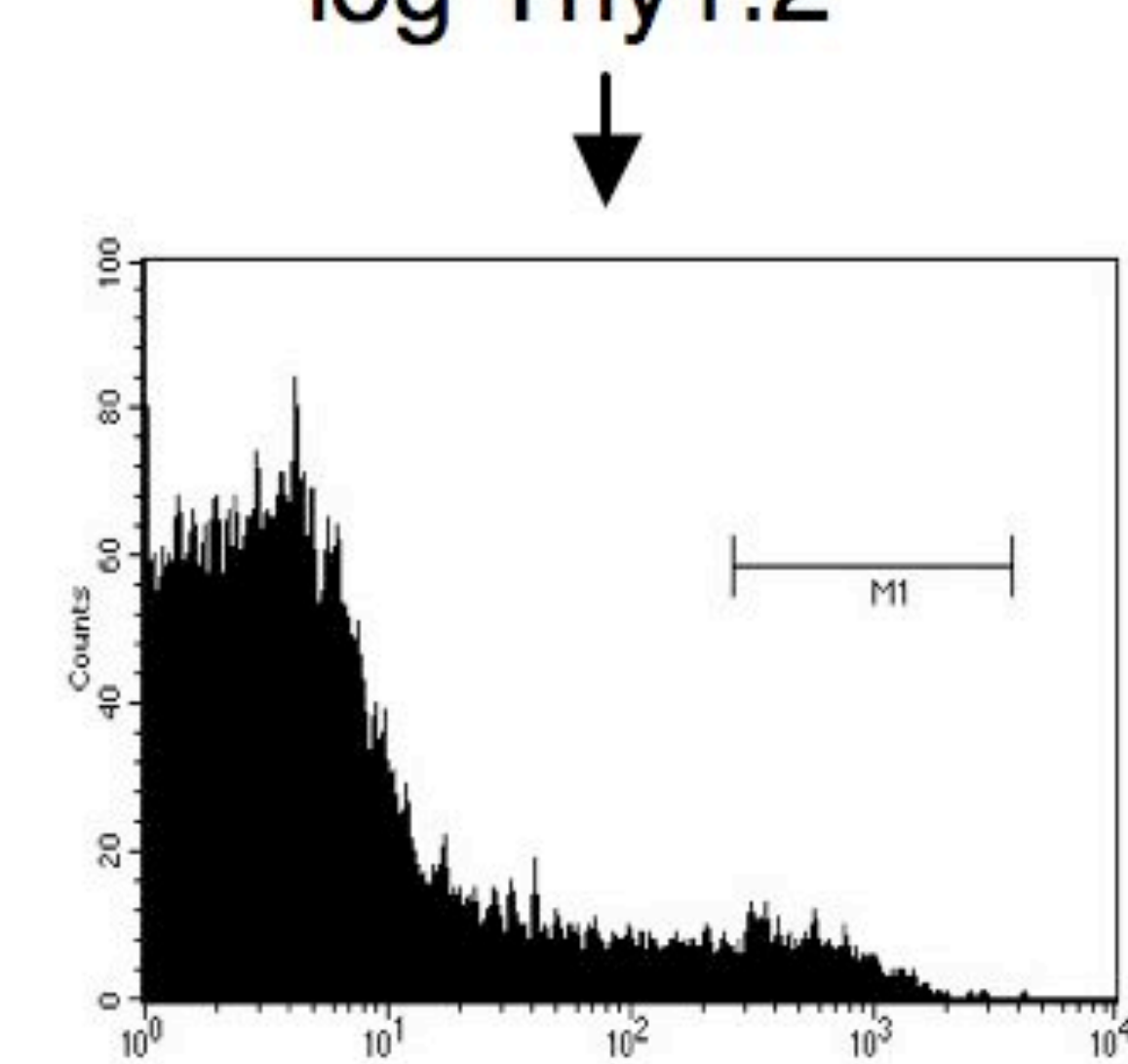

$\log$ CD25

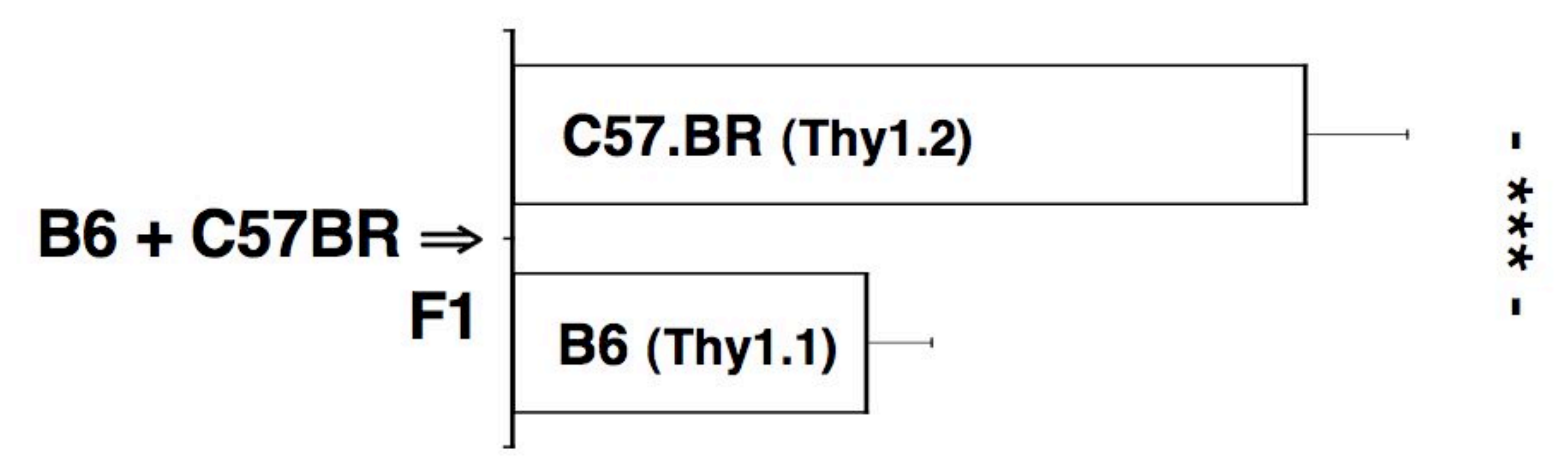

B
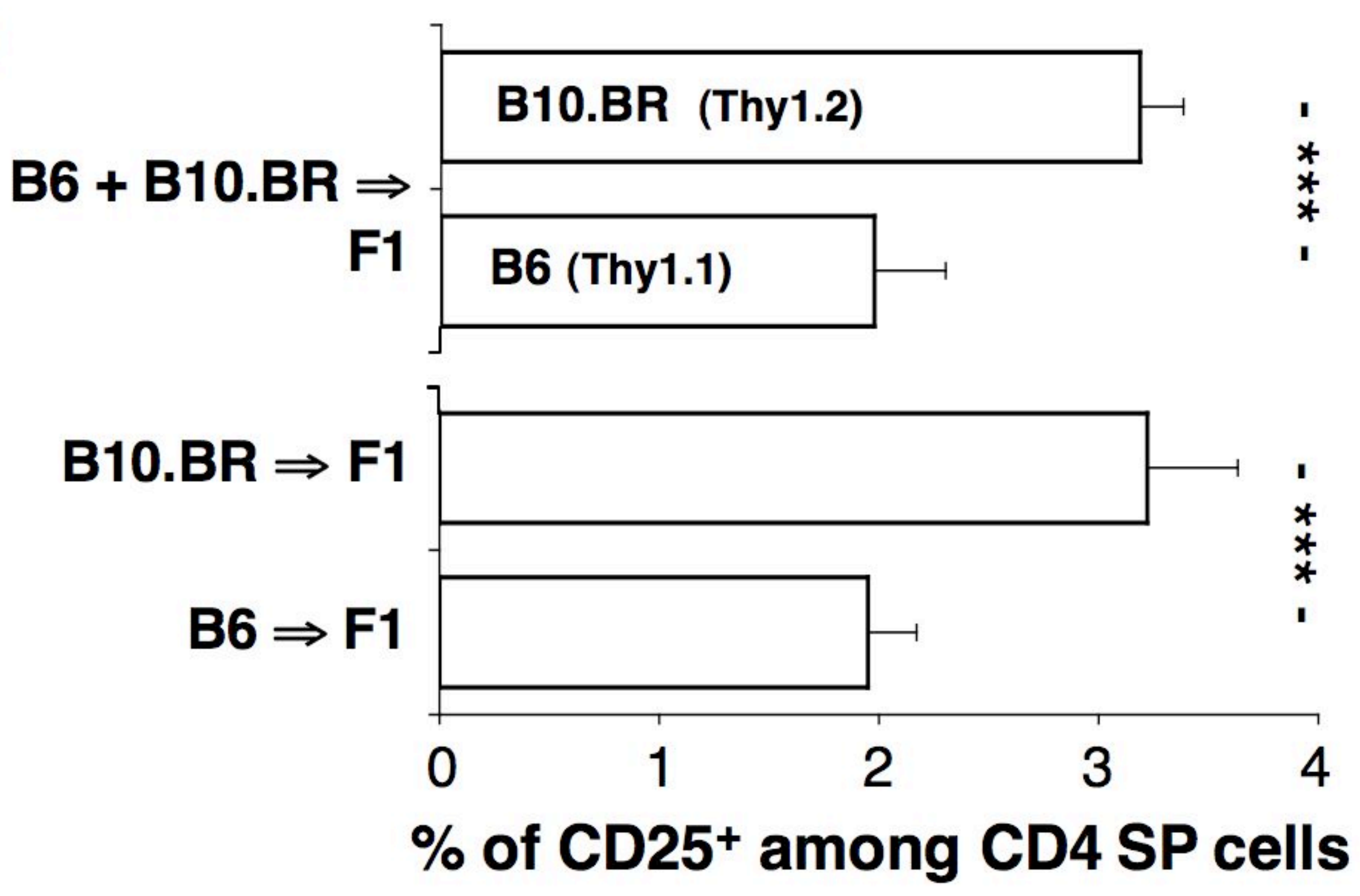
Figure 4

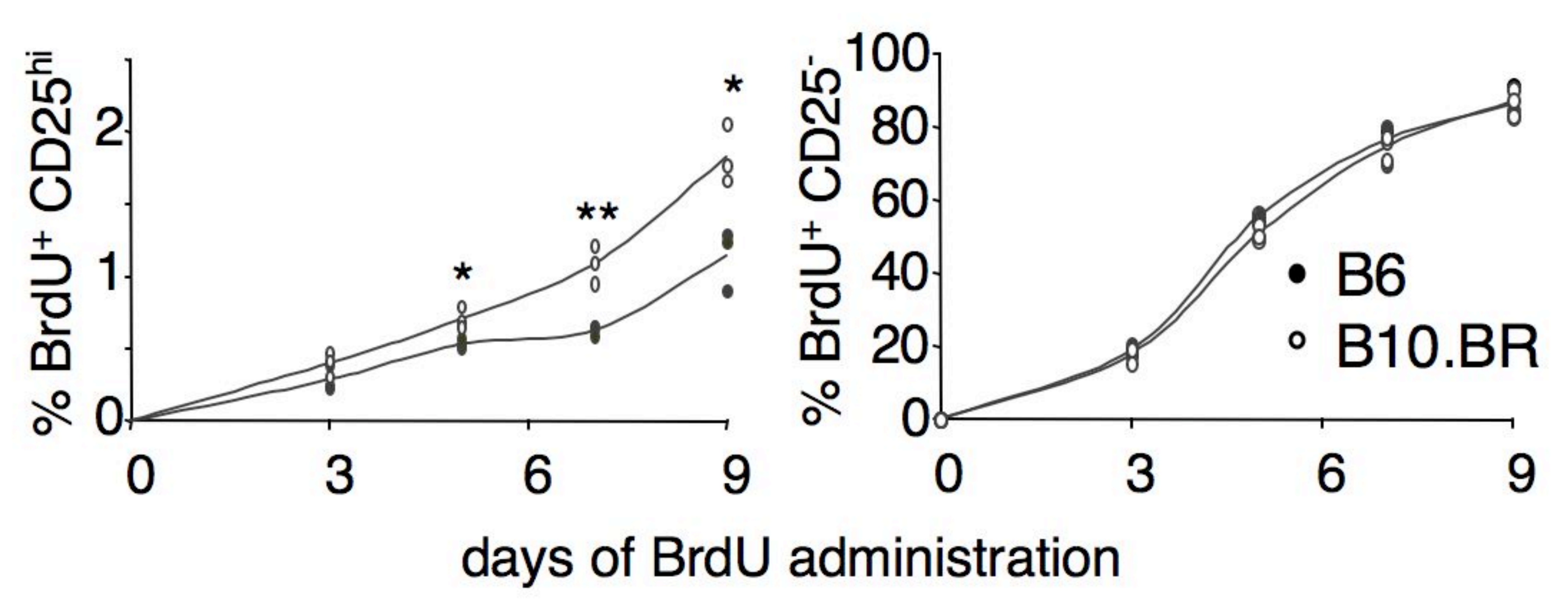




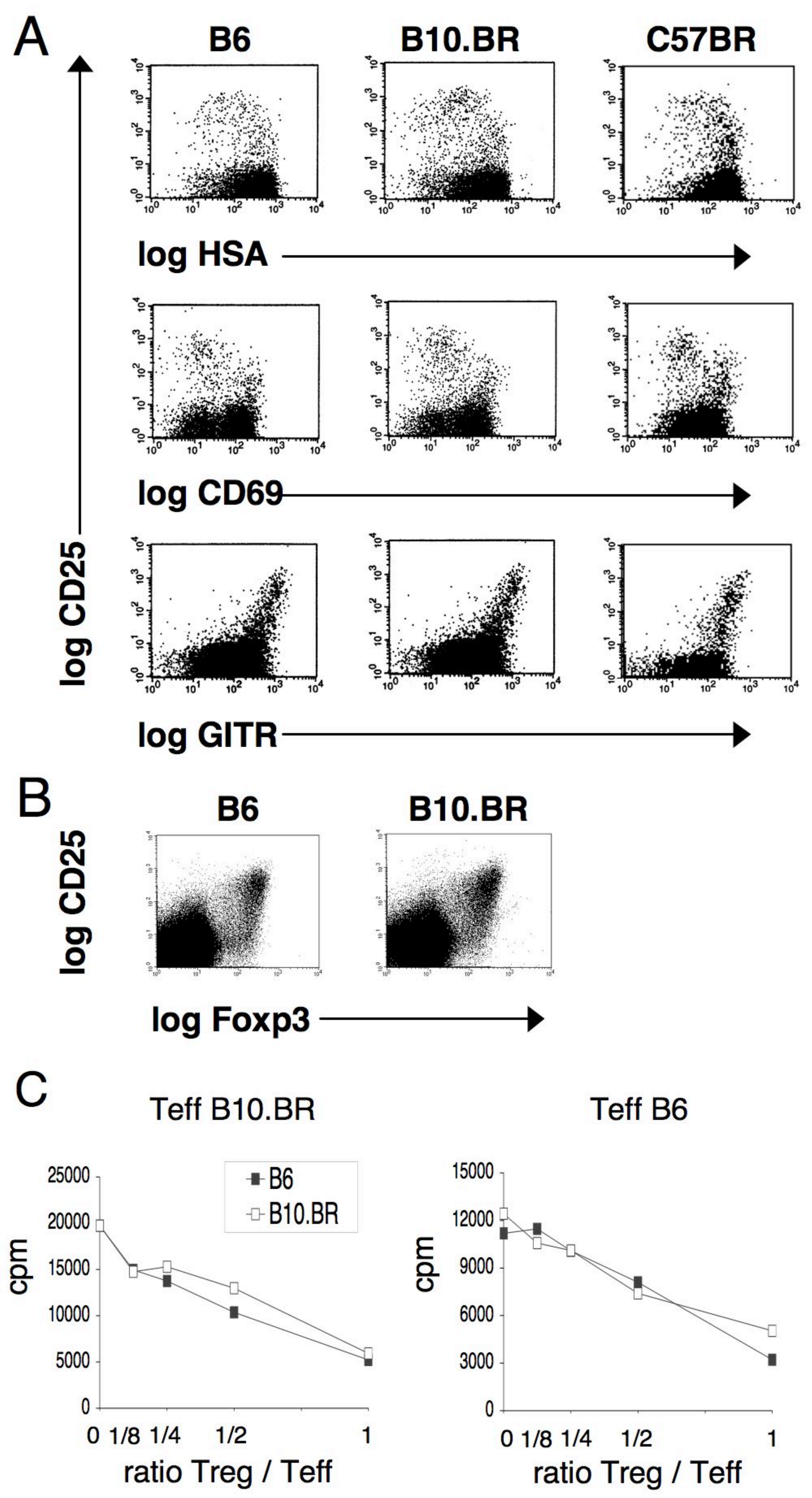


Figure 6
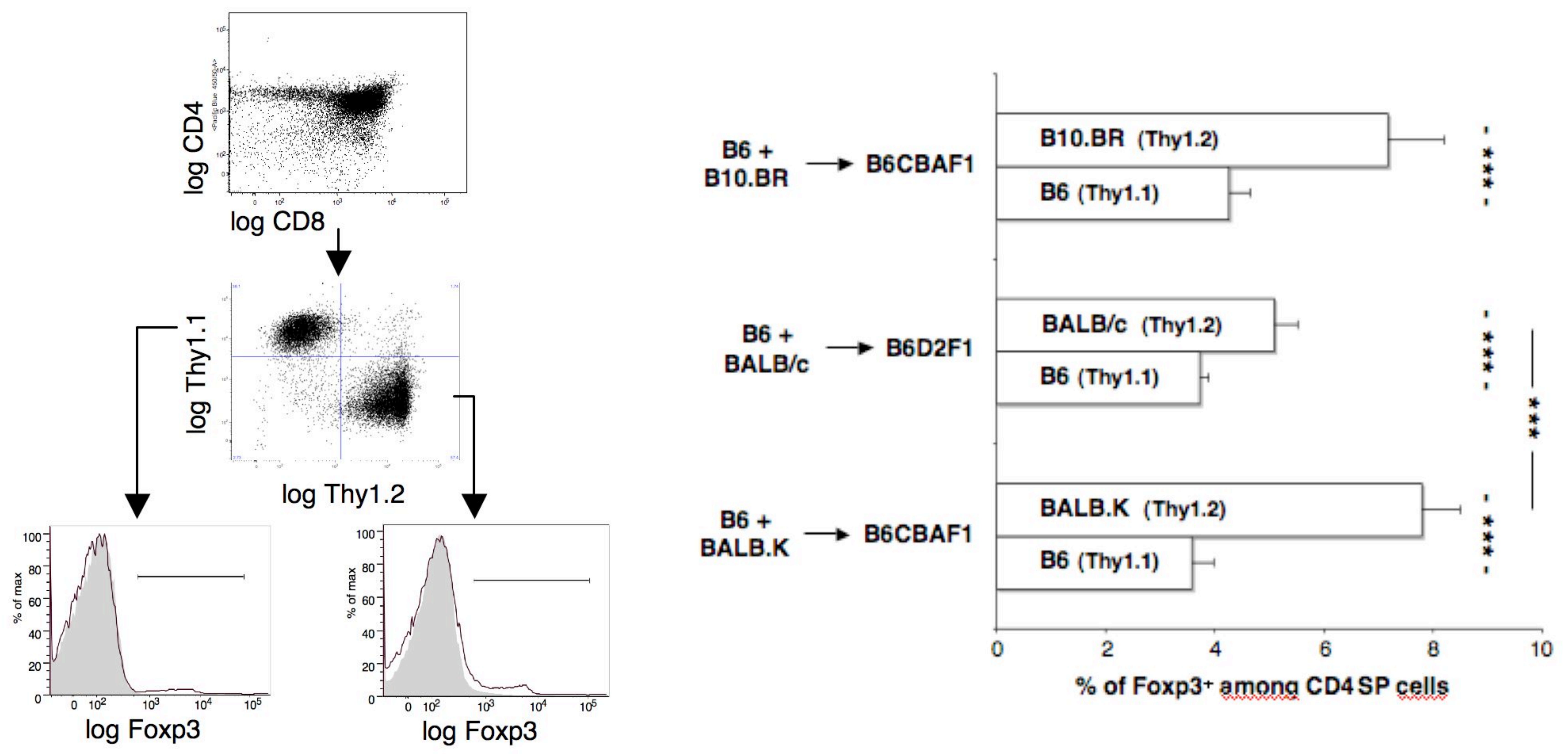

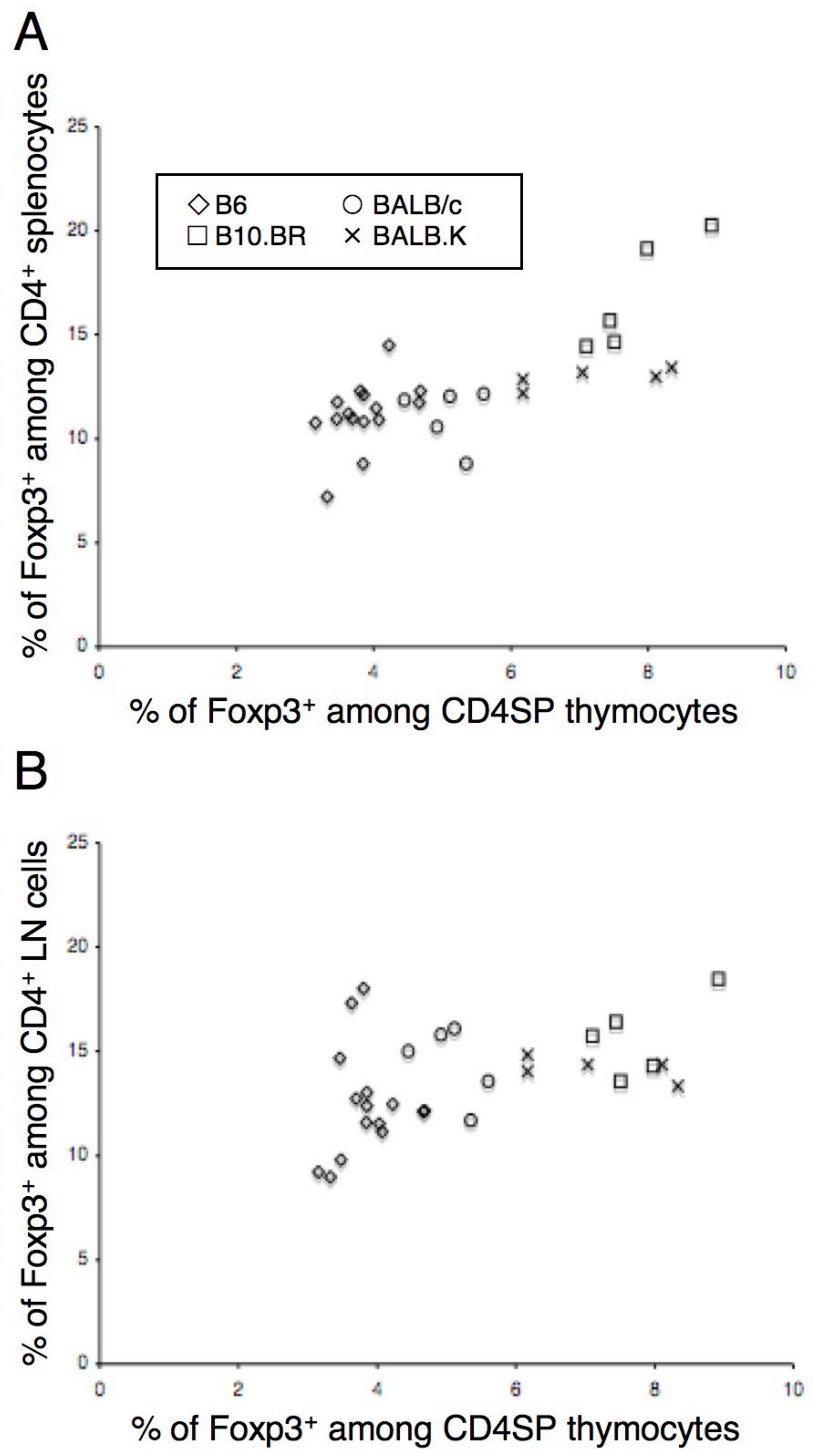
Table 1. Genetic characterization of congenic strains.

\begin{tabular}{lccccccc}
\hline $\begin{array}{l}\text { microsatellite } \\
\text { markers }\end{array}$ & $\begin{array}{c}\text { physical } \\
\text { distance }\end{array}$ & B10.BR & B10.A & B10.A(2R) & BALB.K & B10.D2 & B10.S \\
\hline D17mit164 & 3.89 & BR & B6 & B6 & & & B6 \\
D17mit171 & 6.98 & & B6 & B6 & & B6 & \\
D17mit57 & 8.5 & BR & B6 & B6 & & DBA2 & \\
D17mit114 & 11.06 & & & & Balb & & B6 \\
D17mit79 & 11.24 & BR & & & & & B6 \\
D17mit133 & 22.66 & & B6 & B6 & & DBA2 & SJL \\
D17mit100 & 23.97 & & B6 & B6 & & DBA2 & \\
D17mit229 & 28.53 & & B6 & B6 & Balb & & \\
D17mit63 & 30.32 & & & & Balb & DBA2 & SJL \\
D17mit230 & 30.38 & & & & C3H & & \\
D17mit16 & 31.30 & & B6 & B6 & C3H & DBA2 & SJL \\
D17mit28 & 31.70 & BR & B6 & B6 & C3H & DBA2 & SJL \\
D17mit231 & 32.23 & BR & A & A & & & SJL \\
D17mit34 & 32.44 & BR & A & A & C3H & DBA2 & SJL \\
D17mit32 & 32.45 & BR & A & A & C3H & & \\
D17mit214 & 32.94 & BR & A & A & & DBA2 & \\
D17mit233 & 33.66 & BR & A & B6 & & DBA2 & SJL \\
D17mit47 & 33.97 & BR & A & B6 & & DBA2 & SJL \\
D17mit125 & 34.25 & BR & A & B6 & C3H & & SJL \\
D17mit148 & 35.10 & & B6 & B6 & & DBA2 & \\
D17mit24 & 35.26 & & & & C3H & DBA2 & SJL \\
D17mit234 & 36.83 & & & & C3H & DBA2 & SJL \\
D17mit176 & 40.25 & BR & B6 & B6 & C3H & & SJL \\
D17mit36 & 44.33 & & & & Balb & DBA2 & B6 \\
D17mit250 & 44.98 & & B6 & B6 & & B6 & B6 \\
D17mit177 & 46.08 & & B6 & B6 & & B6 & B6 \\
D17mit6 & 50.14 & & B6 & B6 & & B6 & B6
\end{tabular}

Physical distances (in megabases) were retrieved with the Ensembl browser (available from www.ensembl.org). Markers belonging to the chromosomal region introgressed into the recipient strains in congenic lines are in bold. 